\title{
Nocturnal surface ozone enhancement over Portugal during winter: Influence of different atmospheric conditions
}

\author{
Pavan S. Kulkarni ${ }^{1}$, Hari Prasad Dasari ${ }^{2}$, Ashish Sharma ${ }^{3}$, D. Bortoli ${ }^{1,4}$, Rui \\ Salgado $^{1,5}$ and A. M. Silva ${ }^{1,5}$
}

\author{
${ }^{1}$ Instituto de Ciências da Terra (ICT), University of Évora, Évora, Portugal \\ ${ }^{2}$ King Abdullah University of Science and Technology (KAUST), Physical Sciences and \\ Engineering Division, Thuwal, Saudi Arabia \\ ${ }^{3}$ Department of Civil \& Environmental Engineering and Earth Sciences (CEEES) and the \\ Environmental Change Initiative, University of Notre Dame, IN, USA \\ ${ }^{4}$ Institute for Atmospheric Science and Climate (ISAC-CNR), Bologna, Italy \\ ${ }^{5}$ Department of Physics, University of Évora, Évora, Portugal
}

Corresponding author: Pavan S. Kulkarni, Geophysics Centre of Évora (CGE), University of Évora, Évora, Portugal

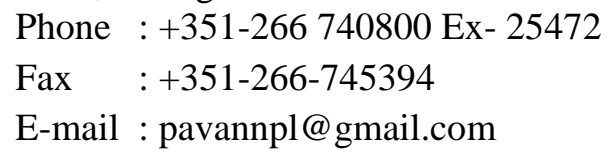

\begin{abstract}
Four distinct nocturnal surface ozone (NSO) enhancement events were observed, with NSO concentration exceeding $80 \mu \mathrm{g} / \mathrm{m}^{3}$, at multiple ozone $\left(\mathrm{O}_{3}\right)$ monitoring stations $(32$ sites) in January, November and December between year 2000 to 2010, in Portugal. The reasonable explanation for the observed bimodal pattern of surface ozone with enhanced NSO concentration during nighttime has to be transport processes, as the surface ozone production ceases at nighttime. Simultaneous measurements of $\mathrm{O}_{3}$ at multiple stations during the study period in Portugal suggest that horizontal advection alone cannot explain the observed NSO enhancement. Thus, detailed analysis of the atmospheric conditions, simulated with the Weather Research and Forecasting (WRF) model, were performed to evaluate the atmospheric mechanisms responsible for NSO enhancement in the region. Simulations revealed that each event occurred as a result of one or the combination of different atmospheric processes such as, passage of a cold front followed by a subsidence zone; passage of a moving surface trough, with associated strong horizontal wind speed and vertical shear; combination of vertical and horizontal transport at the synoptic scale; formation of a low level jet with associated vertical mixing below the jet stream. The study confirmed that large-scale flow pattern resulting in enhanced vertical mixing in the nocturnal boundary layer, plays a key role in the NSO enhancement events, which frequently occur over Portugal during winter months.
\end{abstract}

Keywords: NSO enhancement; WRF model; vertical mixing; low-level jet 


\section{Introduction}

Surface ozone $\left(\mathrm{O}_{3}\right)$ is a photo-chemically produced, highly reactive, secondary air pollutant and an important greenhouse gas (West and Fiore, 2005). Under clear sky conditions $\mathrm{O}_{3}$ exhibits marked diurnal variability, particularly at urban and suburban areas and less prominent at rural areas. $\mathrm{O}_{3}$ concentration starts increasing after sunrise, due to initialization of photochemical production involving nitrogen oxides ( $\mathrm{NO}$ and $\mathrm{NO}_{2}$ ) and volatile organic compounds (VOCs), and reaches the maximum concentration during early afternoon. $\mathrm{O}_{3}$ concentration sharply decreases during late afternoon, while at night, due to surface deposition and chemical destruction, minimum values of $\mathrm{O}_{3}$ concentration are measured (Zhang et al., 2004). In the presence of stable nocturnal boundary layer (NBL), $\mathrm{O}_{3}$ generally has a positive gradient from the surface to the top of the NBL (Geyer and Stutz, 2004; Stutz et al., 2004) due to insufficient downward mixing because of the nocturnal capping (Kuang et al., 2011). The aforementioned pattern of $\mathrm{O}_{3}$ diurnal variation is observed almost routinely, although occasional enhancement of nocturnal surface ozone (NSO) is reported at various sites by many researchers (Coulter, 1990; Corsmeier et al., 1997; Jain et al., 2005; Hu et al., 2012; Kulkarni et al., 2013, 2015; Klein et al., 2014). As photochemical production of $\mathrm{O}_{3}$ ceases at nighttime and in the absence of any known sources of $\mathrm{O}_{3}$ in the NBL, NSO enhancement can only be attributed to transport processes (Salmond and McKendry, 2002) influenced by favorable atmospheric conditions.

Various possible mechanisms for the NSO enhancement are proposed, such as mountain valley wind system and vertical mixing (Sanchez et al., 2005), land and sea breeze (Nair et al., 2002), horizontal transport (Sousa et al., 2011), role of low-level jet (LLJ) associated with vertical mixing (Corsmeier et al., 1997; Klein et al., 2014), titration of urban ozone in the late afternoon/early evening followed by vertical mixing (Chan et al., 1998; Leung and Zhang, 2001), and transport due to vertical wind (W) from residual layer (Sanchez et al., 2007). Depending on various conditions such as the geographical location, boundary layer dynamics, topography, type of environment (urban, suburban and rural) and local weather conditions, any one of the proposed mechanisms was considered responsible for the NSO enhancement. Some studies of NSO enhancement are reported all over the world but mostly on a single event, over a single site or small region (with few monitoring sites) with almost no repetition over the same study area, with some exceptions of Sousa et al. (2011) and Kulkarni et al. (2013, 2015). Due to aforementioned reasons, there is still no consensus among researchers on the mechanisms that lead to the NSO enhancement. Further, the study of NSO enhancements remains a challenge, since its occurrence cannot be predicted accurately and thus, it is difficult to plan an extensive field experiment due to financial constraints among others.

The adverse effects of high daytime $\mathrm{O}_{3}$ concentration on flora and fauna and on human health are well established (Menezes and Shively, 2001; Anenberg et al., 2009). High NSO concentration, during NSO enhancement events (exceeding $80 \mu \mathrm{g} / \mathrm{m}^{3}$, which is more than $\mathrm{O}_{3}$ exposure index AOT40 (2008/50/CE Directive)), has harmful effects on vegetation and plants, particularly in C3 and C4 plant species (Segschneider et al., 
1995; Musselman and Massman, 1999; Musselman and Minnick, 2000; Takahashi et al., 2005), causing water loss and reduced whole-plant production (Matyssek et al., 1995). However, the adverse effects of high NSO concentration, during NSO enhancement events, on the human health are still not studied as on one hand NSO is well below $60 \mathrm{ppb}\left(120 \mu \mathrm{g} / \mathrm{m}^{3}\right)$ threshold set by European Directives EU60 and, on the other hand, during nighttime, particularly in winter, the outdoor human activities are normally diminished eventually inexistent. The NSO enhancement is basically the spatial redistribution of ozone by vertical mixing from lower free troposphere or within the nocturnal boundary layer, which may be important since it may affect the photochemistry of the following day therefore the overall air quality (Ravishankara, 2009). Furthermore, enhanced NSO can result in increased absorption of the outgoing longwave radiation causing localized warming due to greenhouse effect (West and Fiore, 2005; Kulkarni et al., 2013).

The general opinion about NSO enhancement is that it is highly variable in time and space (Löffler-Mang et al., 1997) and considered as an isolated or a special event. However, Sousa et al. (2011) analyzed hourly $\mathrm{O}_{3}$ data for the period 2005-2007 from 4 stations in Portugal and found it to be more frequent. They further concluded that there was a close relationship between wind direction and the observed NSO enhancement. Similarly, Kulkarni et al. (2013) analyzed long term (2000-2010) hourly $\mathrm{O}_{3}$ data and reported that (i) NSO concentration exceeded $40 \mu \mathrm{g} / \mathrm{m}^{3}, 60 \mu \mathrm{g} / \mathrm{m}^{3}$ and $80 \mu \mathrm{g} / \mathrm{m}^{3}$ on more than $50 \%, 20 \%$ and $2 \%$ of the days respectively, during the study period, and (ii) observed a increasing trend in the NSO concentration over Portugal. The studies by Sousa et al. (2011) and Kulkarni et al. (2013) have performed statistical analysis, but lack to identify and perform in-depth analysis to determine the specific reasons for the NSO enhancement.

The aim of this study is to perform in-depth analysis four NSO enhancement events and investigate the role of different atmospheric mechanisms responsible for repetitive occurrence of these events of varying periods and intensities with concentration exceeding $80 \mu \mathrm{g} / \mathrm{m}^{3}$, over Portugal, using both observational data and modeled simulations. The Weather Research and Forecasting (WRF) regional climate model (V3.7.1) (Skamarock et al., 2008) was used to study the influence of atmospheric conditions, and inferred possible ozone transport mechanisms due to vertical mixing from residual layer or from the free troposphere to the surface (Jaffe, 2011) during NSO enhancement events over Portugal.

\section{Study area, data and method}

Portugal is located on the Iberian Peninsula and is surrounded by the Atlantic Ocean in the west and south coasts, and bordered by Spain in the north and east sides. It is located between $37^{\circ}$ and $42^{\circ} \mathrm{N}$ latitudes, and $10^{\circ}$ and $6^{\circ} \mathrm{W}$ longitudes. In order to take into account the spatial variation of the climatological and topographic conditions and to facilitate the data analysis and interpretation, Portugal is categorized into two regions, namely (I) North of Portugal (NoP) and (II) South of Portugal (SoP) (Figure 1a) broadly following Koppen-Geiger Climate Classification. In general, NoP has 
Mediterranean climate with humid warm summers and mild rainy winters whereas, SoP has subtropical Mediterranean climate with mild winters and medium hot summers. The NoP is mountainous with several plateaus indented by river valleys, whereas the SoP is characterized by rolling plains.

\subsection{Surface ozone observation}

Hourly records of $\mathrm{O}_{3}$ concentrations are obtained from 32 air quality monitoring stations, representing different type of environment (urban, suburban and rural) and type of influence (background, traffic and industrial), spatially distributed all over Portugal (Figure 1a). All of these stations belong to the Portuguese Environmental Agency APA network (http://www.qualar.org/). In this study, only sites with $>90 \%$ data coverage for the whole period of our interest are used for analysis.

Table 1 gives detailed list of stations with information such as name of the stations, latitude-longitude-altitudes, type of environment, type of influence, operational status and data availability (\%). 12 of the 32 monitoring stations are located in the NoP and the remaining 20 in the SoP. Monitoring stations are well scattered in the respective regions as shown in Figure 1(a), but are mainly clustered in and around Porto in the NoP and Lisbon in the SoP, the two biggest metropolitan areas in the respective regions.

\subsection{Criteria to identify the NSO enhancement events}

In this study, four distinct events of NSO enhancement (Table 2) were identified to investigate the repetitive occurrence of NSO events over the same geographical area (Portugal), based on the following criteria:

1. NSO concentration $>80 \mu \mathrm{g} / \mathrm{m}^{3}$ at multiple stations: NSO concentration exceeded 80 $\mu \mathrm{g} / \mathrm{m}^{3}$ at $5,6,13$ and 15 stations in event 1 to event 4 respectively out of 30 stations used in the study, covering a large geographical area (Portugal).

2. Month of occurrence, duration and intensity of the events: At least one NSO enhancement event per month of the winter season was chosen i.e one in November, one in December and two in January. The choice of one event per month was made keeping in mind that Portugal has a variety of synoptic and meteorological conditions during the winter season. Also, the duration of the event (varying between 1 night [event 3] to 6 nights [event 2]) and its intensity (with maximum average NSO concentration of $79 \mu \mathrm{g} / \mathrm{m}^{3}$ in the SoP) were considered.

\subsection{Model description}

A non-hydrostatic, compressible WRF regional climate model (Version 3.7.1; Skamarock et al. 2005, 2008) was used for the simulation of atmospheric processes during NSO enhancement events. Figure 1b shows three two-way nested domains with terrain height and grid spacing (grid points) of 9-km (400x400), 3-km (652x553) and 1$\mathrm{km}(751 \times 1000)$. The outermost domain is large enough to capture any synoptic activity contained within the domain boundaries. A large spatial outermost domain also provided degrees of freedom to develop its own synoptic and mesoscale circulations. The model had 40 sigma vertical levels from the surface to $50 \mathrm{hPa}$. 
The innermost (1-km) domain covers continental Portugal and adjoining ocean. The three dimensional initial atmospheric fields and the time varying boundary conditions are taken from the NCEP FNL data available at 1-degree latitude-longitude resolution and at 6 hour interval (http://rda.ucar.edu/datasets/ds083.2/). Sea surface temperatures are updated with 6-hourly intervals using NCEP Real-time SST archives (ftp://polar.ncep.noaa.gov/pub/history/sst). Simulations were conducted with daily initializations at 1200 UTC and integrated up to a 36-hour lead-time for each set of events. The first 12-hour time period is considered as a spin up time and the subsequent 24 hours are considered for analysis till the end of simulation period (Pan et al.1995; Qian et al. 2003; Lucas-Picher et al. 2013; Langodan et al. 2014, 2015, Viswanadhapalli et al. 2016).The model outputs are generated every 15 minutes interval for the inner domain. The terrain, land use and soil data are interpolated to the model grids from USGS global elevation, 24 category USGS vegetation data and 17 category FAO Soil data with suitable spatial resolution (30 seconds) for surface boundary conditions. The study uses the full-suite of model physics parameterizations which are presented in Table S1 (Supplementary material). Because of the versatility of the WRF model usage in simulating atmospheric processes at multiple spatial resolutions (meso-scale at $\sim 50$ $\mathrm{km}$ to local scales at $\sim 50 \mathrm{~m}$ ) (Heikkilä et al. 2011; Sharma and Huang 2012; Talbot et al. 2012; Conry et al. 2015), we performed WRF model simulations at 1-km horizontal resolution to explicitly resolve convection and vertical velocity to study NSO enhancement events.

\section{Results and discussion}

\subsection{Model inter-comparisons with observations}

The model simulated air temperature at $2 \mathrm{~m}$ altitude and wind speed at $10 \mathrm{~m}$ which were compared with observed temperature (Figure 2a) and wind speed (not shown here) using data from 17 weather stations belonging to the Portuguese Institute for Sea and Atmosphere (IPMA). Figure 2a compares the diurnal variations of spatial averaged surface air temperature at 17 stations with simulated surface air temperature for all four events (Table 2). For all events, diurnal variations of observed temperature at 1 hour interval were reasonably well reproduced by WRF. However, in events 1 and 3 simulated temperature minima where lower than the observed temperature. Figure $2 \mathrm{~b}$ shows the scatter plots between spatial averaged observed and simulated temperatures for all four events. The root mean square error (RMSE) and correlation coefficient were calculated and were found to be in the range of $0.87{ }^{\circ} \mathrm{C}-1.60{ }^{\circ} \mathrm{C}$ and $0.94-0.97$, respectively. In general, these results indicate that simulated temperatures compared well with the observed temperatures thus, the model setup can be used for detailed analysis of the specific atmospheric mechanisms responsible for the four selected NSO enhancement events.

\subsection{NSO enhancement events}

Four distinctive and prominent NSO enhancement events over Portugal were examined. In all the four events, NSO enhancement was observed at multiple $\mathrm{O}_{3}$ 
monitoring stations in the winter months of year 2000-2010. The duration of the NSO enhancement events lasted between 2 to 6 nights depending on the local and on the synoptic conditions over Portugal during the event. In the analysis that follows, all $\mathrm{O}_{3}$ concentration values including NSO concentration values are average of 20 monitoring stations from the SoP and of 12 monitoring stations from the NoP regions respectively, unless otherwise stated. All the time notations are in UTC, which also happens to be local time in Portugal during winter.

To understand the influence of different atmospheric conditions and the transport processes responsible for NSO enhancements, various simulated meteorological variables were selected for the analysis of each one of the four events. The chosen model simulated outputs were: horizontal wind speed and direction and sea level pressure at the synoptic scale; vertical wind, potential temperature, horizontal wind speed and direction at various vertical levels at mesoscale. The Beaufort nomenclature is used in the analysis of wind speed.

\subsubsection{January 2006 event:}

The first event considered in this study, started at around 2000 UTC of 5 Jan 2006 and lasted till 0400 UTC of the 7 Jan 2006 (Figure 3). In the afternoon of 5, before the start of the event, the daytime spatially averaged peak $\mathrm{O}_{3}$ concentration reached the value of $50 \pm 12 \mu \mathrm{g} / \mathrm{m}^{3}$ (hereafter numbers following ' \pm ' is for standard deviation) in the SoP and $36 \pm 22 \mu \mathrm{g} / \mathrm{m}^{3}$ in the NoP. In the evening of the same day, just before the start of the event, the spatially averaged $\mathrm{O}_{3}$ concentration reached the minimum value of $36 \pm 24$ $\mu \mathrm{g} / \mathrm{m}^{3}$ in the SoP and $21 \pm 22 \mu \mathrm{g} / \mathrm{m}^{3}$ in the NoP. After sunset, in the absence of photochemical production of $\mathrm{O}_{3}$, the NSO concentration should stay low.

However, during the late evening of the 5 Jan, the $\mathrm{O}_{3}$ concentration started increasing again and it reached secondary maxima next day early morning in both regions $\left(70 \pm 10 \mu \mathrm{g} / \mathrm{m}^{3}\right.$ in the $\mathrm{SoP}$ and $69 \pm 11 \mu \mathrm{g} / \mathrm{m}^{3}$ in the NoP). The observed $\mathrm{O}_{3}$ concentration increase was $34 \mu \mathrm{g} / \mathrm{m}^{3}$ in the SoP and $48 \mu \mathrm{g} / \mathrm{m}^{3}$ in the NoP compared to the evening minima. After reaching secondary maxima, the $\mathrm{O}_{3}$ concentration started to decrease and reached minima at around 0800 UTC for both the regions. The observed NSO enhancement shows a bimodal structure in the diurnal variation of $\mathrm{O}_{3}$. On the 6 Jan at 0500 UTC, the NSO concentrations were higher than the peak $\mathrm{O}_{3}$ concentration observed on the 5 Jan afternoon. The maximum NSO concentration recorded in the SoP region during this event was at Monte Velho (rural background) monitoring site (88 $\mu \mathrm{g} / \mathrm{m}^{3}$ ), however high NSO concentration $\left(81 \mu \mathrm{g} / \mathrm{m}^{3}\right)$ was also observed at Mem Martins (urban background) monitoring site along with other urban sites. Similarly, maximum NSO concentration recorded in the NoP region was at Fornelo do Monte (rural background) monitoring site $\left(85 \mu \mathrm{g} / \mathrm{m}^{3}\right)$, but at the same time several urban and suburban sites observed high NSO concentration $\left(>70 \mu \mathrm{g} / \mathrm{m}^{3}\right)$. On the last night of the event, the NSO concentrations were less than the ones on the 6 early morning over the SoP and subsided over the NoP. In Figure 3, it can be noticed that apart from bimodal structure in the diurnal variation of $\mathrm{O}_{3}$, spatial variability (standard deviation) of $\mathrm{O}_{3}$ 
concentration in the diurnal variation also shows large changes. The most interesting point worth noting is the low value of the standard deviation associated with the averaged high NSO value, compared to previous afternoon's high value of the standard deviation, indicating uniform high NSO concentration over a large part of Portugal, emphasizing the large spatial coverage and high intensity of this event. The reasonable explanation for the observed high NSO concentration with a secondary peak after midnight has to be transport processes, as ozone production ceases at nighttime.

During this event, the synoptic situation is characterized by the passage of a cold frontal system with the associated low pressure centered in the Bay of Biscay, north of Iberian Peninsula (Figure 4a). Along the Portuguese coast, the large scale circulation is from Northwest, bringing maritime air (Figure 4b). Both the height-latitude as well as the height-longitude cross-sections (Figure 4c to 4i) showed strong downdraft over both the SoP and the NoP regions. The downdrafts had a depth of over $3 \mathrm{~km}$ and were compensated by the existence of updrafts over other areas in the same region, under an unstable frontal environment. Following the motion of the system, the location of these vertical circulations changed overnight, creating a well-mixed low troposphere. This mixing process brought ozone rich upper air, down to the surface. Changes in the vertical winds were accompanied by trough and ridge regions of potential temperature (black lines in Figure 4c to 4i) and strong vertical wind was observed on potential temperature trough regions. At around $0400 \mathrm{UTC}$ on the $6 \mathrm{Jan}$, the simulated downdrafts over both the SoP and the NoP regions were greater than $1 \mathrm{~ms}^{-1}$ in some columns from the surface up to $3 \mathrm{~km}$ and above with high variability in the potential temperature (Figure 4c to 4i) with gale to strong-gale NW horizontal winds (Figure 4b). The NW horizontal winds were observed over the Atlantic Ocean and over Portugal, which suggests that the horizontal transport of vertically descended $\mathrm{O}_{3}$ over the Atlantic Ocean along Portuguese coast occurred in the post cold front sector. On 7 Jan at 0300 UTC, the SoP experienced again a small NSO enhancement (with maximum NSO concentration of $50 \mu \mathrm{g} / \mathrm{m}^{3}$ ) whereas no NSO enhancement was observed over NoP. This supports the hypothesis that the NSO enhancement on the last night of this event was due to the combination of downdraft of the air behind the passage of a cold front and horizontal transport mechanisms over a large area.

\subsubsection{December 2006 event:}

The second event was the longest one compared to the remaining three events analyzed in this study, starting on the evening of 1 Dec 2006 and continued till the morning of 7 Dec 2006 (Figure 5). During this event, the maximum average NSO concentrations were $>60 \mu \mathrm{g} / \mathrm{m}^{3}$ on 5 nights and 4 nights out of 6 nights respectively over the SoP and NoP region. On the nights of the $3 \mathrm{Dec}$ and the $6 \mathrm{Dec}$, the average NSO concentrations were comparatively low with a high standard deviation over the SoP and the NoP. Further analysis of NSO concentration observed on 3 and 6 Dec at each station revealed that high NSO concentrations were also observed at almost all the stations but at different time of the night resulting in low average NSO concentrations for the entire night period with high standard deviation values. 
The synoptic situation was characterized by the passage of a moving surface trough, elongated over Portugal (Figure 6a). The convergence line associated to the trough separates a region of northwestern winds, in the west sector, and another one of southwestern winds, in the east sector. The large-scale atmospheric flow pattern shows the presence of two high-pressure systems on both east (land area) and west (ocean) sides of Portugal (Figure 6a). The nights with higher NSO values were characterized by the passage of the convergence line over the coastal regions on the $2 \mathrm{Dec}$ during the midnight, $5 \mathrm{Dec}$ in the early morning and on $6 \mathrm{Dec}$ in the late evening, or by the existence of an instability line on the $4 \mathrm{Dec}$. The downdrafts were greater than $1 \mathrm{~ms}^{-1}$ on the $2 \mathrm{Dec}$ and showed high day-to-day variability from the $2 \mathrm{Dec}$ to the $6 \mathrm{Dec}$ late night. The downdraft subsided on the $7 \mathrm{Dec}$ early morning to $0.05 \mathrm{~ms}^{-1}$ over the entire Portugal.

This type of synoptic-scale system enhanced the wind speed over Portugal and was persisted for a long period. Figure $6 \mathrm{~b}$ shows a narrow strip of the downdraft which was observed over the Atlantic Ocean along Portugal, between $37.5^{\circ} \mathrm{N}$ till $38.7^{\circ} \mathrm{N}$, which continued along the coast of Portugal with higher intensity till $40.8^{\circ} \mathrm{N}$. Figure $6 \mathrm{c}$ to $6 \mathrm{~h}$ shows simulated downdraft with intensity slightly higher than $1 \mathrm{~ms}^{-1}$ in several narrow regions extending from the surface up to $3 \mathrm{~km}$ altitude and a steep trough in the potential temperature.The recurrent occurrence of prolonged NSO events with high intensity, like this one, may likely be harmful for flora and fauna (Musselman and Massman, 2000; Musselman and Minnick, 2000) and for local population.

\subsubsection{November 2007 event:}

The third event, which occurred on the 8 and 9 Nov 2007, was the smallest but the severest of the four events analyzed in this study (Figure 7). On 8 Nov at 2000 UTC, the $\mathrm{O}_{3}$ concentrations were $25 \pm 25 \mu \mathrm{g} / \mathrm{m}^{3}$ and $24 \pm 35 \mu \mathrm{g} / \mathrm{m}^{3}$, respectively over the SoP and the NoP regions. On the $9 \mathrm{Nov}$ at $0400 \mathrm{UTC}, \mathrm{O}_{3}$ concentration started to increase over the SoP and reached a maximum concentration of $83 \pm 30 \mu \mathrm{g} / \mathrm{m}^{3}$. NSO concentrations, above $100 \mu \mathrm{g} / \mathrm{m}^{3}$ were observed at 7 out of 15 stations in the SoP, with the highest value of NSO concentration of $119 \mu \mathrm{g} / \mathrm{m}^{3}$ recorded at the Odivelas site, Lisbon. Data from 2 stations located in SoP were not available during this event. However, over the NoP, the $\mathrm{O}_{3}$ concentration remained the same throughout the night (more or less the same $\mathrm{O}_{3}$ concentration observed at 2000 UTC, on 8 Nov) with only 3 stations recording values more than $50 \mu \mathrm{g} / \mathrm{m}^{3}$, with the highest value of NSO concentration of $100 \mu \mathrm{g} / \mathrm{m}^{3}$ recorded at the Fornelo do Monte site in the central Portugal.

Figure 8a shows the synoptic scale horizontal winds $(\mathrm{m} / \mathrm{s})$ and the sea level pressure at 0000 UTC of 9 Nov 2007. The simulated downdraft represented in Figure $8 \mathrm{~b}$ showed a narrow region in the horizontal plane with strong vertical winds at $1.5 \mathrm{~km}$ altitude over the Atlantic Ocean (from North-west corner till central costal Portugal) along with NW wind direction. The vertical winds in the same narrow region moved northward between 0100 UTC to 0330 UTC, along with a change of the wind direction from NW to northerly (Figure 8c and 8d). The simulated downdraft over Portugal was 
slightly higher than $1 \mathrm{~ms}^{-1}$ in several narrow regions extending from $3 \mathrm{~km}$ altitude down to the surface with a steep trough in the potential temperature (Figure 8e to 8k). The combination of horizontal and vertical cross-sections showed a clear pattern which suggests that downdraft started over the Atlantic Ocean and moved towards costal Portugal. During the same period, a change in the wind direction from northwest to northerly was noticed, indicating horizontal transport of vertically descended ozone rich air from free troposphere from over Atlantic Ocean towards continental Portugal, particularly towards the SoP region.

\subsubsection{January 2009 event:}

The fourth event lasted for 4 days from 12 to 15 Jan 2009 (Figure 9). On 12 Jan at $1900 \mathrm{UTC}$, the observed minimum $\mathrm{O}_{3}$ concentrations were $21 \pm 23 \mu \mathrm{g} / \mathrm{m}^{3}$ (SoP) and $29 \pm 27 \mu \mathrm{g} / \mathrm{m}^{3}(\mathrm{NoP})$. After $1900 \mathrm{UTC}$, the $\mathrm{O}_{3}$ concentrations started increasing and at 2200 UTC, the $\mathrm{O}_{3}$ concentration reached $\sim 44 \mu \mathrm{g} / \mathrm{m}^{3}$ over both the SoP and the NoP. The $\mathrm{O}_{3}$ concentration further continued to increase at a faster rate over the SoP, compared to NoP, and reached upto $70 \pm 17 \mu \mathrm{g} / \mathrm{m}^{3}$ at midnight, an increase of $\sim 16 \mu \mathrm{g} / \mathrm{m}^{-}$ 3 in the course of 2 hours during the night. The NSO concentration reached the peak value of $79 \pm 17 \mu \mathrm{g} / \mathrm{m}^{3}$ on $13 \mathrm{Jan}$ at $0400 \mathrm{UTC}$ over SoP, an increase of more than $375 \%$ compared to the evening minimum observed on the 12 Jan at 1900 UTC. On the other hand, over the $\mathrm{NoP}$, the $\mathrm{O}_{3}$ concentration further continued to increase gradually from $\sim 44 \mathrm{~g} / \mathrm{m}^{3}$ observed at $2200 \mathrm{UTC}$ on $12 \mathrm{Jan}$, reaching a maximum $\mathrm{O}_{3}$ concentration of $61 \pm 13 \mu \mathrm{g} / \mathrm{m}^{3}$ at $0400 \mathrm{UTC}$ on the $13 \mathrm{Jan}$.

The synoptic scale horizontal winds and the sea level pressure are shown in Figure 10a. Model simulations showed the formation of a low level jet along the coast of Portugal on the evening of 12 Jan which persisted till late morning (Figure 10b to 10e). Large-scale analysis showed that this was a pre-frontal low-level jet (LLJ) (Figure 10a). The frontal convergence zone separates two wind patterns, one of northwest winds and another one of southwest winds. The cold front moves from northwest to southeast. In the warm sector, the strong southwest LLJ along the coast of Portugal reaches intensities of about $20 \mathrm{~ms}^{-1}$, ahead of the cold front. The movement of the system from the northwest sector to southeast sector of Portugal took about 4-6 hours. The shear associated with the passage of the LLJ enhances turbulent mixing (Figure 10f to 10m) and weakens the decoupling between the residual layer and the stable nocturnal boundary layer (Hu et al., 2013). This allows ozone rich air from residual layer and free troposphere to actively mix with the surface air, causing NSO enhancement at the surface. On 13 night there was no NSO enhancement. Analysis of the simulated vertical wind was performed for the 14 early morning when there was no NSO enhancement and found that vertical wind reached its minimum value over SoP and NoP. However, on 14 evening, after reaching the evening minima, the $\mathrm{O}_{3}$ concentration again started to increase and reached a NSO maximum of $67 \pm 16 \mu \mathrm{g} / \mathrm{m}^{3}(\mathrm{SoP})$ and of $58 \pm 7 \mu \mathrm{g} / \mathrm{m}^{3}$ (NoP) after midnight.

\section{Conclusions}


In this study we have identified and studied four events of NSO enhancement over the same geographical region (Portugal) over a period of 10 years. The WRF model was used to simulate atmospheric processes at high resolution $(1 \mathrm{~km}$ in the horizontal) and to identify different atmospheric transport mechanisms which may have likely been responsible for the NSO enhancements observed over Portugal.

The first NSO enhancement event was caused by enhanced vertical mixing as a result of the passage of a cold front. Reitebuch et al., (2000) also reported the passage of a cold front as responsible for NSO enhancement observed over North RhineWestphalia, Germany, based on air quality and meteorological observations, without model simulations. During the second event, the existence of two high-pressure systems on both sides (east (land area) and west (ocean) sides) of Portugal with the passage of a moving surface trough, elongated over Portugal, with associated strong horizontal wind speed and vertical shear, persisted for a long period, causing downdrafts and NSO enhancement which lasted for several days. Similar prolonged period of high ozone concentration with multiple high NSO events was also observed at San Bernardino, Alpine valley (Prevot et al., 2000), but not due to same atmospheric mechanisms. The third event shows that, under strong vertical winds in a narrow horizontal region, the NSO enhancement can be intense and even exceed the daytime $\mathrm{O}_{3}$ concentrations. This event also shows the occurrence of NSO enhancement due to the combination of vertical mixing and horizontal transport mechanisms over a large area. Eliasson et al., (2003) also reported that the combination of vertical mixing and horizontal transport mechanism was responsible for NSO enhancement over the city of Göteborg, but it occurred during summer over a smaller geographical area (single city) and was based on air quality and meteorological observations, without model simulations. The enhancement of NSO during the fourth event was due to the formation of a LLJ along the Portuguese coast, which is associated with vertical mixing below the jet stream. Klein et al., (2014) also studied the role of LLJ on vertical mixing and downward transport of $\mathrm{O}_{3}$ resulting in the NSO enhancement event, using observations and model simulation, over the Oklahoma metropolitan area, which is a landlocked area, more than $600 \mathrm{~km}$ from nearest coast.

NSO enhancement event is considered as an anomaly and highly variable in time and space (Löffler-Mang et al., 1997). The aforementioned NSO enhancement events, that occurred in different geographical areas and studied by Reitebuch et al., (2000), Prevot et al., (2000), Eliasson et al., (2003) and Klein et al., (2014) were considered as special events and single atmospheric mechanism was proposed to explain each one of them. However, this study of NSO enhancement events, using long term (2000-2010) observations as well as model simulations, for the first time shows that NSO enhancement events may occur (a) frequently over the same geographical area (in this case over Portugal) (b) with large spatial-temporal coverage (c) with high $\mathrm{O}_{3}$ concentration values (d) during the winter months and (e) due to one and/or combination of different atmospheric mechanisms, at both synoptic and/or mesoscale. Moreover, large scale flow patterns that favor vertical downdrafts seem to play a major role in the NSO enhancement events. 
Further in-depth study of NSO enhancement with observed data and model simulations is required to fully understand the processes and implications, particularly with observed increasing trend in the background tropospheric ozone (Logan et al., 2012) due to climate change.

\section{Acknowledgement}

The first author (Pavan S Kulkarni) is thankful to Fundação para a Ciência e a Tecnologia (FCT) for the grant SFRH/BPD/82033/2011. The paper was partially funded through FEDER (ProgramaOperacionalFactores de Competitividade COMPETE) and National funding through FCT - Fundação para a Ciência e a Tecnologia in the framework of project FCOMP-01-0124-FEDER-014024 (Ref ${ }^{a}$. FCT PTDC/AAC-CLI/114031/2009). The work is co-funded by the European Union through the European Regional Development Fund, included in the COMPETE 2020 (Operational Program Competitiveness and Internationalization) through the ICT project (UID / GEO / 04683/2013) with the reference POCI-01-0145-FEDER007690.Ashish Sharma was supported by the Notre Dame Environmental Change Initiative and the Center for Sustainable Energy. Authors are thankful to APA (http://qualar.apambiente.pt/) for ozone data, IPMA for meteorological data and NCEP, USA for NNRP/FNL reanalysis data. 


\section{References}

Anenberg, S.C., West, J.J., Fiore, A.M., Jaffe, D.A., Prather, M.J., Bergmann, D., Cuvelier, K., Dentener, F.J., Duncan, B.N., Gauss, M., Hess, P., Jonson, J.E., Lupu, A., MacKenzie, I.A., Marmer, E., Park, R.J., Sanderson, M.G., Schultz, M., Shindell, D.T., Szopa, S., Vivanco, M.G., Wild, O., Zang G., 2009. Intercontinental impacts of ozone pollution on human mortality. Environ. Sci. Technol., 43, 64826487.

Chan, L.Y., Chan, C.Y., Qin, Y., 1998. Surface ozone pattern in Hong Kong. J. App. Meteorology, 37 (10), 1153-1165.

Conry, P., Sharma, A., Potosnak, M.J., Leo, L.S., Bensman, E., Hellmann, J.J., Fernando, H.J.S., 2015. Chicago's Heat Island and Climate Change: Bridging the Scales via Dynamical Downscaling. J. App. Meteoro. and Clim., 54(7), 1430-1448.

Corsmeier, U., Kalthoff, N., Kolle, O., Kotzian, M., Fiedler, F., 1997. Ozone concentration jump in the stable nocturnal boundary layer during a LLJ-event. Atmos. Environ., 31, 1977-1989.

Coulter, R.L., 1990.A case study of turbulence in the stable nocturnal boundary layer. Boundary-Layer Meteorol., 52, 75-91.

Dudhia, J., 1989: Numerical study of convection observed during the winter monsoon experiment using a mesoscale two-dimensional model, J. Atmos. Sci.,46 , 30773107.

Eliasson, I., Thorsson, S., Andersson-Skolfd, Y., 2003. Summer nocturnal ozone maxima in Goteborg, Sweden. Atmos. Environ., 37, 2615-2627.

Geyer, A., Stutz, J., 2004. Vertical profiles of NO3, N2O5, O3, and NOx in the nocturnalboundary layer: 2. Model studies on the altitude dependence of compositionand chemistry. J. Geophys. Res., 109, D12307.

Grell, A. G., Devenyi, D., 2002. A generalized approach to parameterizing convection combining ensemble and data assimilation techniques.Geophys. Res. Lett., 29, doi:10.1029/2002GL015311.

Hong, S.-Y., Lim, J.-O.J., 2006. The WRF single-moment 6-class microphysics scheme (WSM6). J. Korean Meteor. Soc., 42 (2), 129-151.

Hu, X-M., Doughty, D.C., Sanchez, K.J., Joseph, E., Fuentes, J.D., 2012.Ozone variability in the atmospheric boundary layer in Maryland and its implications for vertical transport model. Atmos. Environ., 46, 354-364.

Hu, X-M., Klein, P.M., Xue, M., Zhang, F., Doughty, D.C., Forkel, R., Joseph, E., Fuentes, J. D., 2013.Impact of the vertical mixing induced by low-level jets on boundary layer ozone concentration. Atmos. Environ., 70, 123-130.

Jaffe, D., 2011. Relationship between surface and free tropospheric ozone in the western U.S. Environ. Sci. Technol., 45, 432-438.

Jain, S.L., Arya, B.C., Kumar, A., Ghude, S.D., Kulkarni, P.S., 2005.Observational study of surface ozone at New Delhi, India. Int. J. Remote Sensing, 26 (16), 35153526.

Klein, P.M., Hu. X-M., Xue, M., 2014.Impacts of Mixing Processes in Nocturnal Atmospheric Boundary Layer on Urban Ozone Concentrations. Boundary-Layer Meteorol., 150, 107-130.

Kuang, S., Newchurch, M.J., Burris, J., Wang, L., Buckley, P.I., Johnson, S., Knupp, K., Huang, G., Phillips, D., Cantrell, W., 2011. Nocturnal ozone enhancement in the lower troposphere observed by lidar. Atmos. Environ., 45, 6078-6084. 
Kulkarni, P.S, Bortoli, D., Silva, A.M., Reeves, C., 2015.Enhancements in nocturnal surface ozone at urban sites in the United Kingdom. Environ. Sci. and Pol. Res., 22, 20295 - 20305.

Kulkarni, P.S., Bortoli, D., Silva, A.M., 2013.Nocturnal surface ozone enhancement and trend over urban and suburban sites in Portugal. Atmos. Environ., 71, 251-259.

Langodan, S., Cavaleri, L., Yesubabu, V., Hoteit, I., 2014. The Red Sea: A Natural Laboratory for Wind and Wave Modeling. J. Phys. Oceanogr., 44, 3139-3159.

Langodan, S., Cavaleri, L., Viswanadhapalli, Y., Hoteit, I., 2015. Wind-wave source functions in opposing seas. J. Geophys. Res. Oceans, 120, 6751-6768.

Leung, D.Y.C., Zhang, D.N., 2001. Characteristics of urban ozone level in Hong Kong. J. Environ. Sci., 13(1), 1-7.

Logan, J.A, Staehelin, J., Megretskaia, I.A., Cammas, J.P., Thouret, V., Claude,H., De Backer, H., Steinbacher, M., Scheel, H.-E., Stübi, R., Fröhlich, M., Derwent, R., 2012. Changes in ozone over Europe: Analysis of ozone measurements from sondes, regular aircraft (MOZAIC) and alpine surface sites. J. Geophys. Res., 117, D09301.

Löffler-Mang, M., Kossmann, M., Vogtlin, R., Fiedler, F., 1997.Valley wind systems and their influence on nocturnal ozone concentrations.BeitraegezurPhysikderAtmosphaere, 70, 1-14.

Lucas-Picher, P., Boberg, F., Christensen, J.H., Berg, P., 2013. Dynamical Downscaling with Reinitializations: A Method to Generate Finescale Climate Datasets Suitable for Impact Studies. J. Hydrometeor., 14, 1159-1174.

Matyssek, R., Gunthardt-Goerg, M.S., Maurer, S., Keller, T., 1995. Nighttime exposureto ozone reduces whole-plant production in Betulapendula. Tree Physiol., $15,159-165$.

Menezes, K.A., Shively, T.S., 2001. Estimating the Long-term Trend in the Extreme Values of Tropospheric Ozone Using a Multivariate Approach. Environ. Sci. Technol., 35, 2554-2561.

Musselman, R.C., Massman, W.J., 2000. Ozone flux to vegetation and its relationshipto plant response and ambient air quality standards. Atmos. Environ., 33, 65-73.

Musselman, R.C., Minnick, T.J., 2000. Nocturnal stomatal conductance and ambient air quality standards for ozone. Atmos. Environ., 34, 719-733.

Nair, P.R., Chand, D., Lal, S., Modh, K.S., Naja, M., Parameswaran, K., Ravindran, S., Venkataramani, S., 2002. Temporal variations in surface ozone at Thumba $\left(8.6^{\circ} \mathrm{N}\right.$, $\left.77^{\circ} \mathrm{E}\right)$ - A tropical coastal site in India. Atmos. Environ., 36, 603-610.

Nakanishi, M., Niino, H., 2004. An improved Mellor-Yamada level-3 model with condensation physics: Its design and verification. Bound.-Layer Meteor., 112, 1-31.

Nakanishi, M., Niino, H., 2006. An improved Mellor-Yamada level-3 model: Its numerical stability and application to a regional prediction of advection fog. Bound.Layer Meteor., 119, 397-407.

Pan, Z., Takle, E., Gutowski, W., Turner, R., 1999. Long simulation of regional climate as a sequence of short segments. Mon. Wea. Rev., 127, 308-321.

Prevot, A.S.H., Dommen, J., Baumle, M., Furger, M., 2000.Diurnal variations of volatile organic compounds and local circulation systems in an Alpine valley. Atmos. Environ., 34, 1413-1423.

Qian, J., Seth, A., Zebiak, S., 2003. Reinitialized versus continuous simulations for regional climate downscaling. Mon. Weather Rev., 131(11), 2857-2874.

Ravishankara, A. R., 2009. Are chlorine atoms significant tropospheric free radicals? PNAS, 106 (33), 13639-13640. 
Reitebuch, O., Strassburger, A., Emeis, S., Kuttler, W., 2000. Nocturnal secondary ozone concentration maxima analysed by sodar observations and surface measurements. Atmos. Environ., 34, 4315-4329.

Salmond, J.A., McKendry, I.G., 2002. Secondary ozone maxima in a very stablenocturnal boundary layer: observations from the Lower Fraser Valley, BC. Atmos. Environ., 36, 5771-5782.

Sanchez, M.I., de Torre, B., Garcia, M.A., Perez, I., 2005. Ozone concentrations at a high altitude station in the Central Massif (Spain). Chemosphere, 60, 576-584.

Sanchez, M.I., de Torre, B., Garcia, M.A., Perez, I., 2007. Ground-level ozone and ozone vertical profile measurements close to the foothills of the Guadarrama mountain range (Spain). Atmos. Environ., 41, 1302-1314.

Segschneider, H-J., Wildt, J., Forstel, H., 1995. Uptake of $15 \mathrm{NO} 2$ by sunflower (Helianthusannuus) during exposures in light and darkness: quantities, relationshipto stomatal aperture and incorporation into different nitrogen pools within the plant. New Phytol., 131, 109-119.

Sharma, A., Huang, H-P., 2012. Regional Climate Simulation for Arizona: Impact of Resolution on Precipitation. Advances in Meteorology, vol. 2012, Article ID 505726, 13 pages, 2012. doi:10.1155/2012/505726.

Skamarock, W.C., Klemp, J.B., Dudhia, J., Gill, D.O., Barker, D.M., Duda, M.G., Huang, X-Y., Wang, W., Powers, J.G., 2008.A Description of the Advanced Research WRF Version 3.NCAR Technical Note, NCAR/TN-475+STR. Mesoscale and Microscale Meteorology Division, National Center for Atmospheric Research, Boulder, Colorado, USA.

Soares, P.M.M., Cardoso, R.M., Semedo, A.L., Chinita, M.J., Ranjha, R., 2014. Climatology of the Iberia coastal low-level wind jet: weather research forecasting model high-resolution results. Tellus, 66, 22377.

Sousa, S.I.V., Alvim-Ferraz, M.C.M., Martins, F.G., 2011. Identification and origin of nocturnal ozone maxima at urban and rural areas of Northern Portugal e influence of horizontal transport. Atmos. Environ., 45, 942-956.

Stutz, J., Alicke, B., Ackermann, R., Geyer, A., White, A., Williams, E., 2004. Vertical profiles of NO3, N2O5, O3, and NOx in the nocturnal boundary layer: 1. Observations during the Texas air quality study 2000. J. Geophys. Res., 109, D12306.

Takahashi, M., Konaka, D., Sakamoto, A., Morikawa, H., 2005.Nocturnal uptake andassimilation of nitrogen dioxide by $\mathrm{C} 3$ and CAM plants. Z. Naturforsch Sect. CBiosci., 60, 279-284.

Talbot, C., Bou-Zeid, E., Smith, J., 2012. Nested Mesoscale Large-Eddy Simulations with WRF: Performance in Real Test Cases. J. Hydrometeoro., 13(5), 1421-1441.

Tewari, M., Chen, F., Wang, W., Dudhia, J., Lemone, M.A., Mitchell, K.E., Ek, M., Gayno, G., Wegiel, J.W., Cuenca, R., 2004. Implementation and verification of the unified Noah land-surface model in the WRF model.20th Conference on Weather Analysis and Forecasting/16th Conference on Numerical Weather Prediction, Seattle, WA, American Meteorological Society.

U. Heikkilä, U., Sandvik, A., Sorteberg, A., 2011. Dynamical downscaling of ERA-40 in complex terrain using the WRF regional climate model.Climate Dynamics,37(7), 1551-1564.

Viswanadhapalli, Y., Dasari, H. P., Langodan, S., Challa, V. S. and Hoteit, I. (2016), Climatic features of the Red Sea from a regional assimilative model. Int. J. Climatol.. doi:10.1002/joc.4865 
West, J.J., Fiore A.M., 2005. Management of tropospheric ozone by reducing methane emissions. Environ. Sci. Technol., 39(13), 4685-4691.

Zhang, R., Lei, W., Tie, X., Hess, P., 2004. Industrial emissions cause extreme urban ozone diurnal variability. ProcNatlAcadSci USA, 101(17), 6346-6350. Mlawer, E.J., Taubman, S.J., Brown, P.D., Iacono, M.J., Clough, S.A., 1997. Radiative transfer for inhomogeneous atmosphere: RRTM, a validated correlated-k model for the longwave. J. Geophys. Res., 102 (D14), 16 663-16 682. 
Figure Captions:

Figure 1. (a) Map of Portugal with land use categories and 32 ozone pollution monitoring stations (black dots) (12 in the North of Portugal [NoP] and 20 in the South of Portugal [SoP]) and 17 meteorological stations (blue dots). The red line shown in the map bifurcates Portugal into NoP and SoP. (b) WRF model nested domains: d01 as outermost domain with $9-\mathrm{km}$ grid resolution, intermediate d02 with $3-\mathrm{km}$ resolution, and innermost d04 domain with 1-km resolution.

Figure 2.(a) Averaged diurnal variation of 2-m temperature for all four events. Black squares with line indicate observations and red dots with line are model simulations. (b) Scattered diagram of 2-m observed verses model simulated air temperature for all four events. $\mathrm{R}$ indicates the correlation coefficient and RMSE is the root mean square error.

Figure 3. Averaged diurnal variation of $\mathrm{O}_{3}$ concentration on 5-7 Jan 2006 at 30 air pollution monitoring stations (12 stations from north of Portugal and 18 stations from south of Portugal).

Figure 4. (a) Horizontal winds $(\mathrm{m} / \mathrm{s})$ at $850 \mathrm{hPa}$ level along with the sea level pressure (hPa, shaded) at $9 \mathrm{~km}$ model resolution at 0000 UTC on 6 Jan 2006; (b) Horizontal winds at $1 \mathrm{~km}$ height along with vertical downdraft (shaded) at $1 \mathrm{~km}$ model resolution; (c) and (d) Height-longitude cross section of vertical velocity (shaded) and potential temperature (contours) along $41.1^{\circ} \mathrm{N}$ and $38.8^{\circ} \mathrm{N}$ and; (e) to (i) Height-latitude cross section of vertical velocity (shaded) and potential temperature (contours) along $350.9^{\circ}$, $351.1^{\circ}, 351.3^{\circ}, 351.6^{\circ}$ and $351.8^{\circ}$ at 0345 UTC of 6 Jan 2006.

Figure 5. Averaged diurnal variation of $\mathrm{O}_{3}$ concentration on 1 to $7 \mathrm{Dec} 2006$ at 31 air pollution monitoring stations (12 stations from north of Portugal and 19 stations from south of Portugal).

Figure 6. (a) Horizontal winds $(\mathrm{m} / \mathrm{s})$ at $850 \mathrm{hPa}$ level along with the sea level pressure (hPa, shaded) at $9 \mathrm{~km}$ model resolution at 0000 UTC of 2 Dec 2006; (b) Horizontal winds at $1 \mathrm{~km}$ height along with vertical velocity (shaded) at $1 \mathrm{~km}$ model resolution; (c) and (d) Height-latitude cross section of vertical velocity (shaded) and potential temperature (contours) along $350.6^{\circ}$ and $350.8^{\circ}$ and; (e) to (h) Height-longitude cross section of vertical velocity (shaded) and potential temperature (contours) along $40.9^{\circ} \mathrm{N}$, $40.2^{\circ} \mathrm{N}, 39.6^{\circ} \mathrm{N}$ and $38.8^{\circ} \mathrm{N}$ at $0115 \mathrm{UTC}$ of $2 \mathrm{Dec} 2006$.

Figure 7. Averaged diurnal variation of $\mathrm{O}_{3}$ concentration on 8 and 9 Nov 2007 at 30 air pollution monitoring stations (12 stations from north of Portugal and 18 stations from south of Portugal).

Figure 8. (a) Horizontal winds $(\mathrm{m} / \mathrm{s})$ at $850 \mathrm{hPa}$ level along with the sea level pressure (hPa, shaded) at $9 \mathrm{~km}$ model resolution at 0000 UTC of 9 Nov 2007; (b) to (d) Horizontal winds at $1.5 \mathrm{~km}$ (0100 UTC), 1 (0200 UTC), and 0.7 (0330 UTC) height along with vertical velocity (shaded) at $1 \mathrm{~km}$ model resolution; (e) to (g) Height-latitude 
cross section of vertical velocity (shaded) and potential temperature (contours) along $350.5^{\circ}, 350.6^{\circ}$ and $350.8^{\circ}$ and; (h) to (k) Height-longitude cross section of vertical velocity (shaded) and potential temperature (contours) along $41.2^{\circ} \mathrm{N}, 41.0^{\circ} \mathrm{N}, 40.8^{\circ} \mathrm{N}$ and $39.5^{\circ} \mathrm{N}$ at $0345 \mathrm{UTC}$ of $9 \mathrm{Nov} 2007$.

Figure 9. Averaged diurnal variation of $\mathrm{O}_{3}$ concentration on 12 to $15 \mathrm{Jan} 2009$ at 31 air pollution monitoring stations (12 stations from north of Portugal and 19 stations from south of Portugal).

Figure 10. (a) Horizontal winds (m/s) at $850 \mathrm{hPa}$ level along with the sea level pressure (hPa, shaded) at $9 \mathrm{~km}$ model resolution at 0000 UTC of 13 Jan 2009; (b) to (e) Horizontal winds at $0.3,0.5,0.7$ and $1 \mathrm{~km}$ height along with vertical velocity (shaded) at $1 \mathrm{~km}$ model resolution at $0345 \mathrm{UTC}$ of $13^{\text {th }} \mathrm{Jan}$., 2009; (f) to (i) Height-latitude cross section of vertical velocity (shaded) and potential temperature (contours) along $351.0^{\circ}$, $351.1^{\circ}, 351.2^{\circ}$ and $351.3^{\circ}$ respectively at $0345 \mathrm{UTC}$ of $13 \mathrm{Jan} 2009$, and; (j) to (m) Height-longitude cross section of vertical velocity (shaded) and potential temperature (contours) along $41.0^{\circ} \mathrm{N}$ (0345 UTC), 39.3 ${ }^{\circ} \mathrm{N}$ (0230 UTC), 38.9 $\mathrm{N}$ (0345 UTC) and $38.5^{\circ} \mathrm{N}$ (0100 UTC) of 13 Jan 2009. 

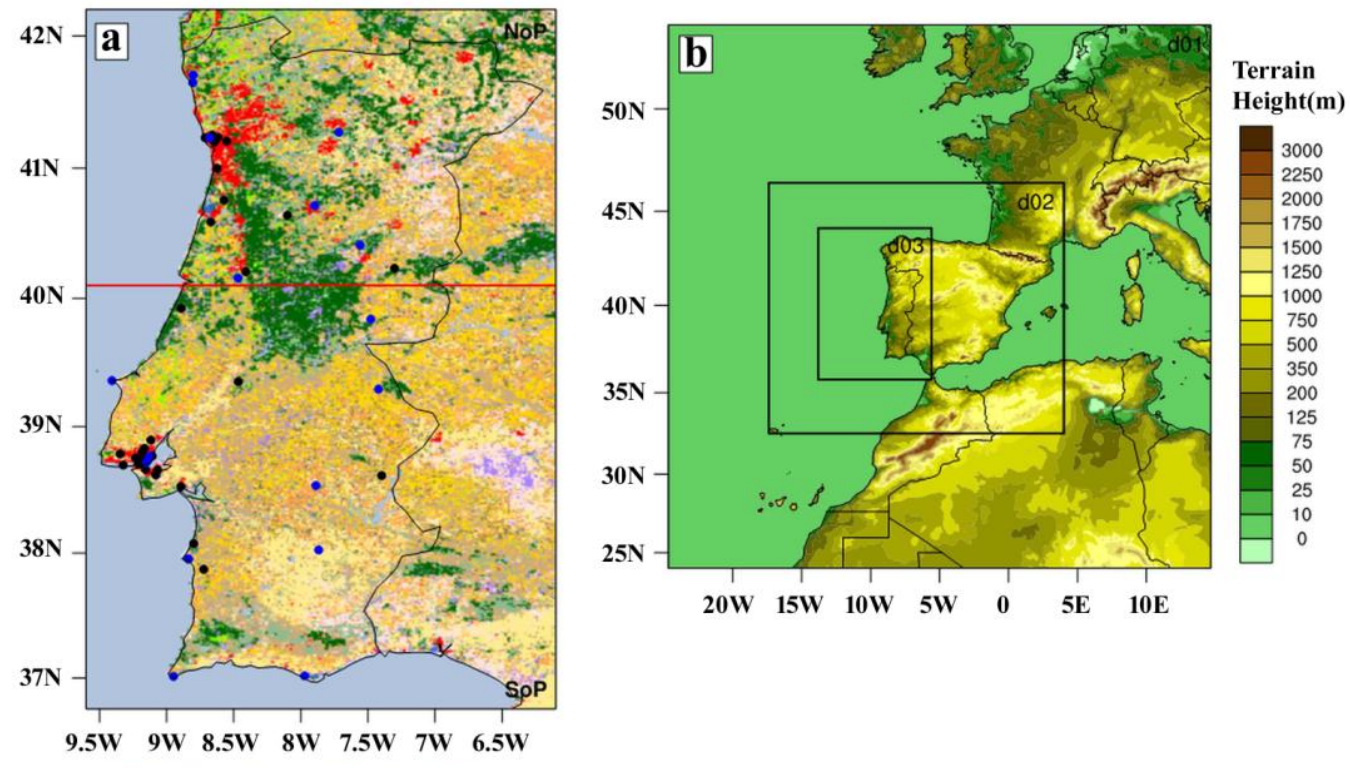

\begin{tabular}{l|l|l|l|l|l|l|l|l|l|l|}
\hline 2 & 3 & 4 & 5 & 6 & 7 & 8 & 9 & $10|11| 12|13| 14|16| 17$ \\
LULC
\end{tabular}

1 Evergreen Needleleaf 5 Mixed Forest

2 Evergreen Broadleaf

3 Deciduous Needleleaf

4 Deciduous Broadleaf
6 Closed Shrubland

7 Open Shrublands

8 Woody Savannas
9 Savannas

10 Grasslands

11 Permanent Wetlands 12 Croplands
13 Urban and Built-Up

14 Cropland Mosaics

15 Barren/Sparse

16 Water 


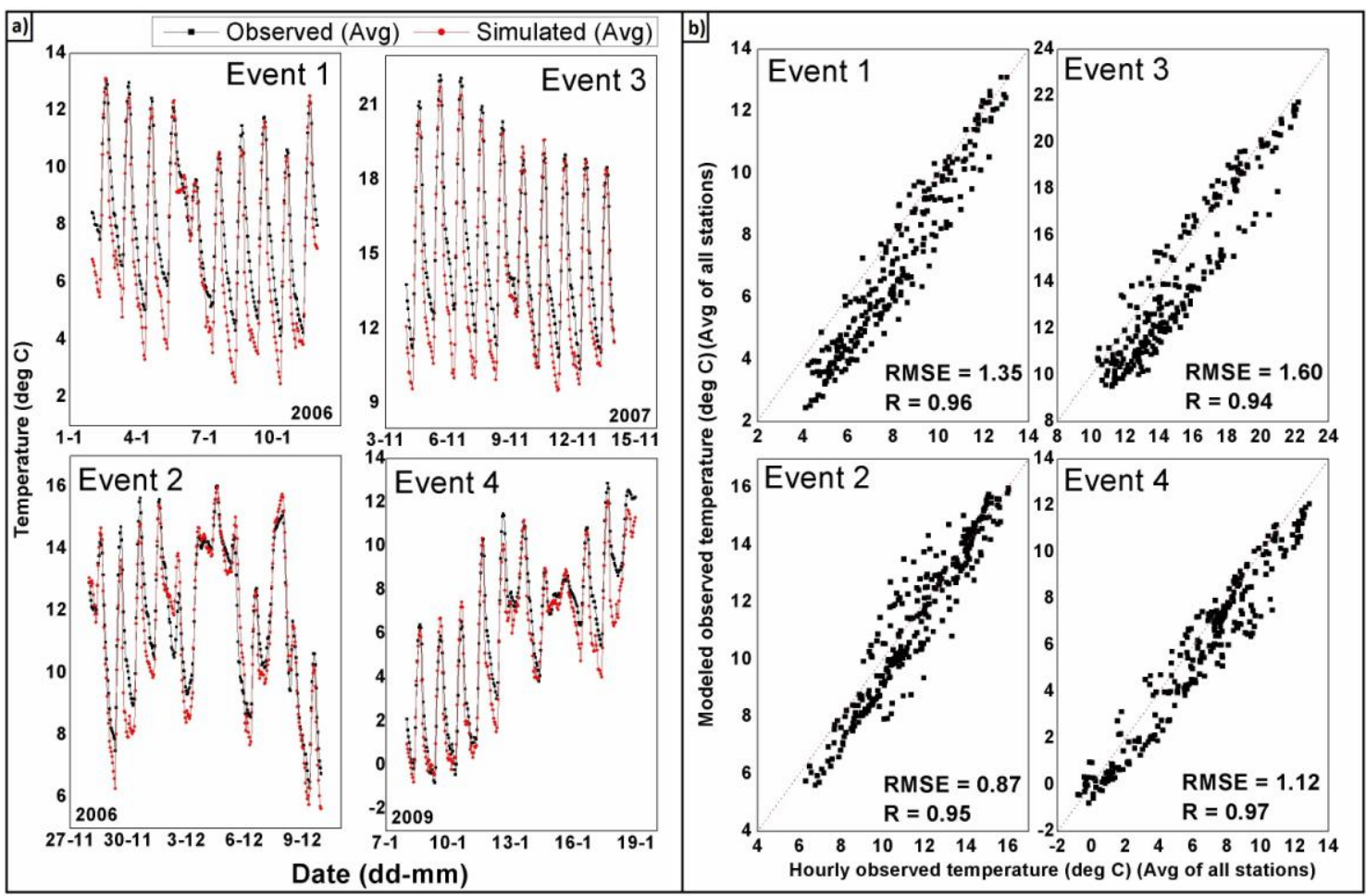




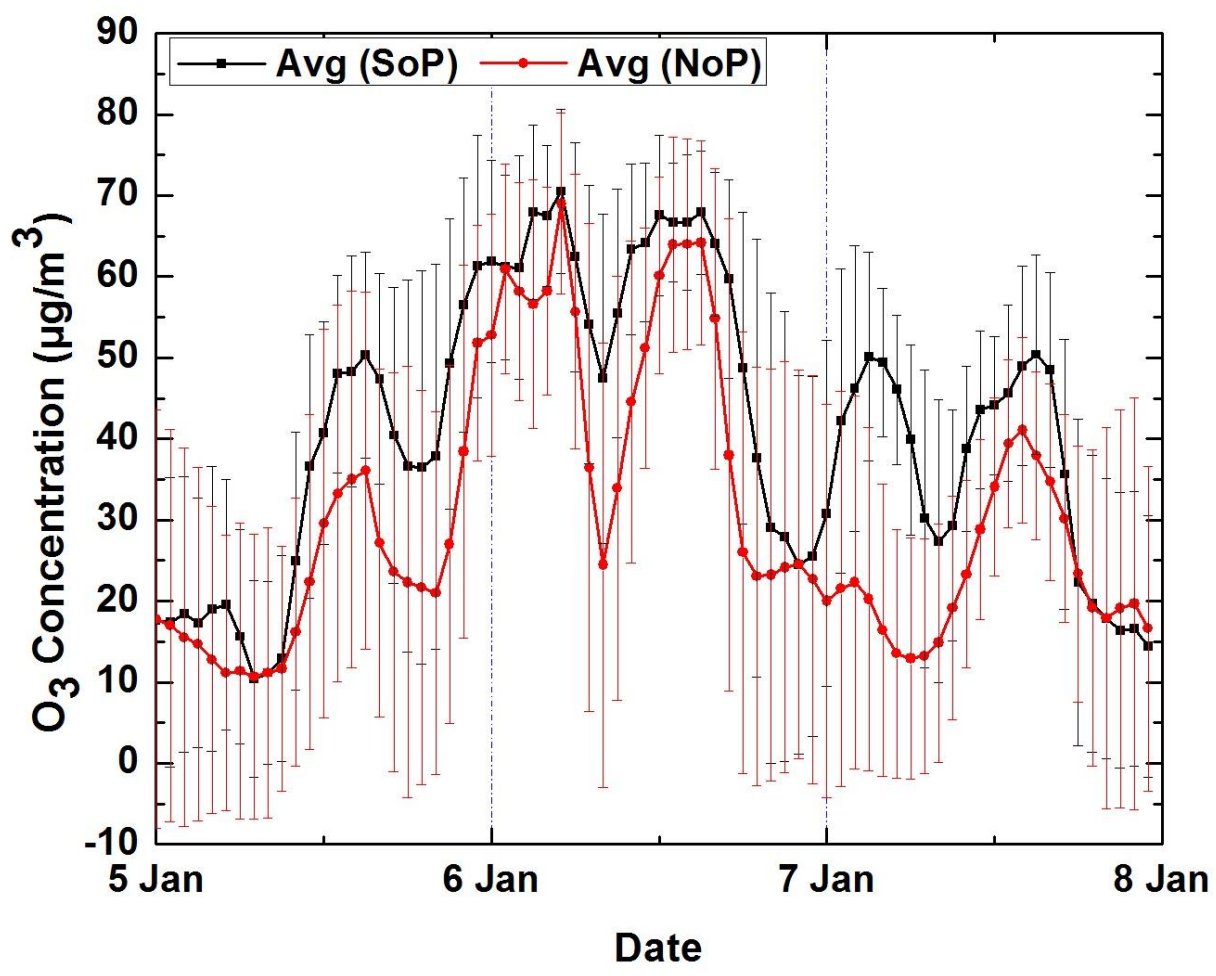




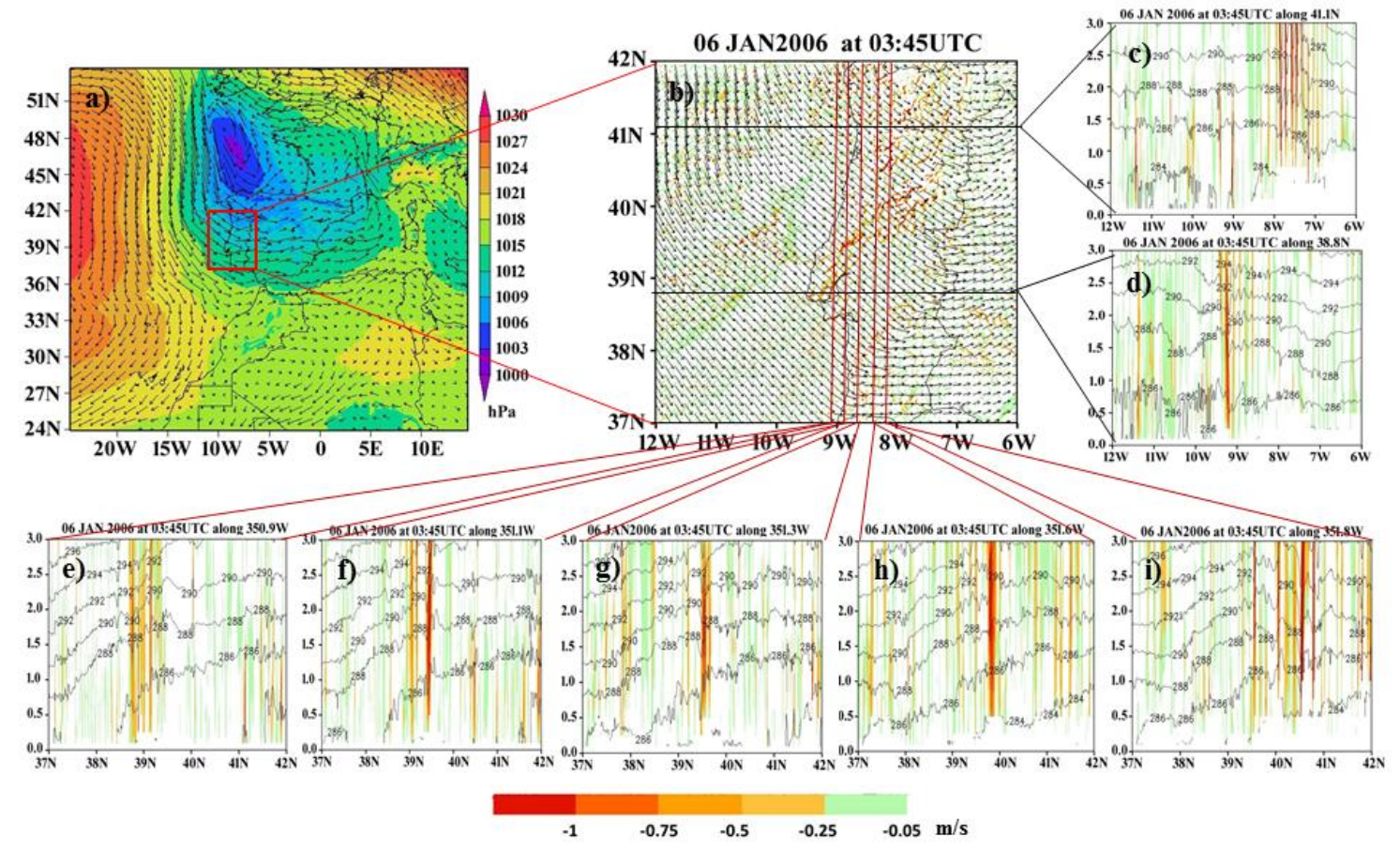




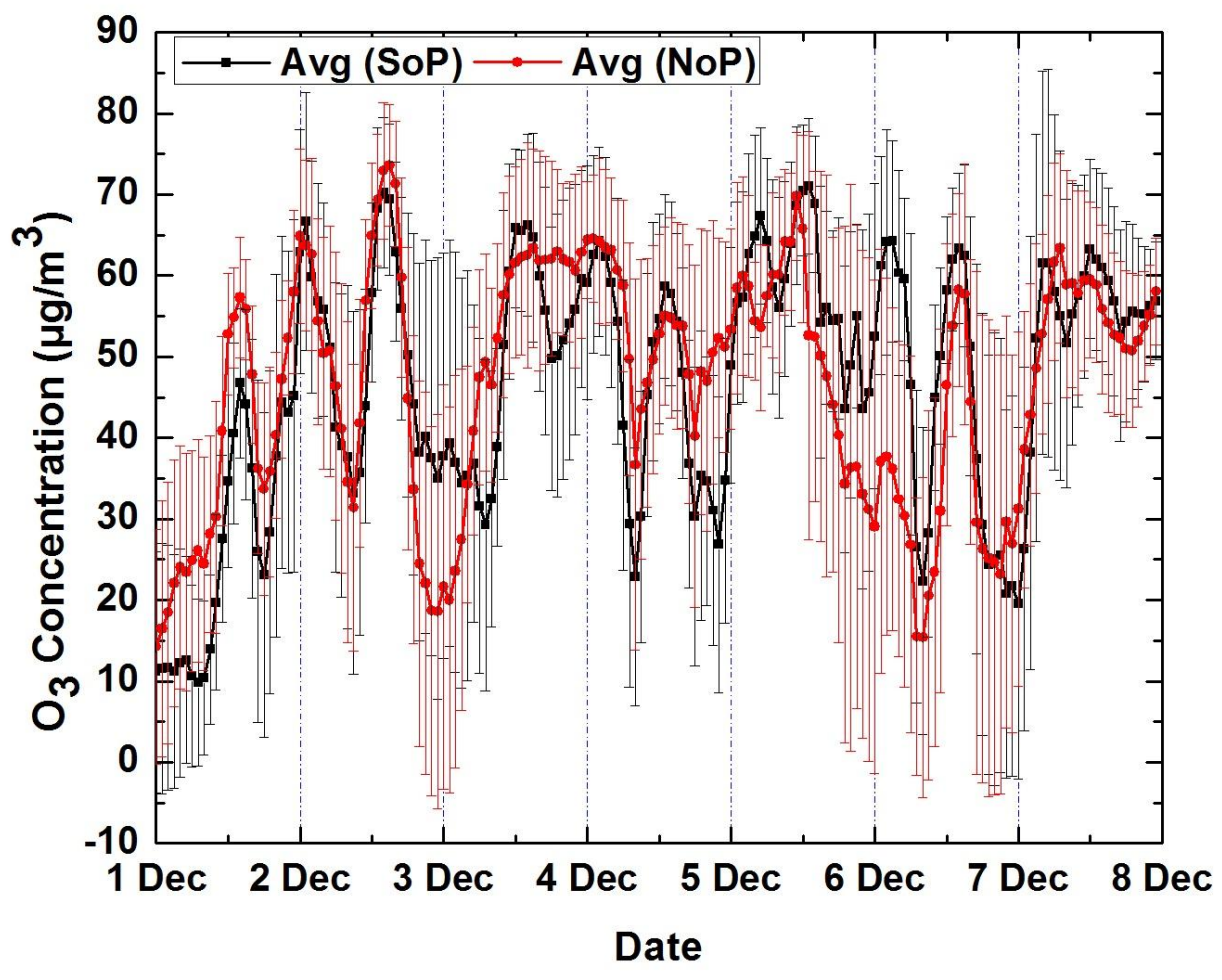




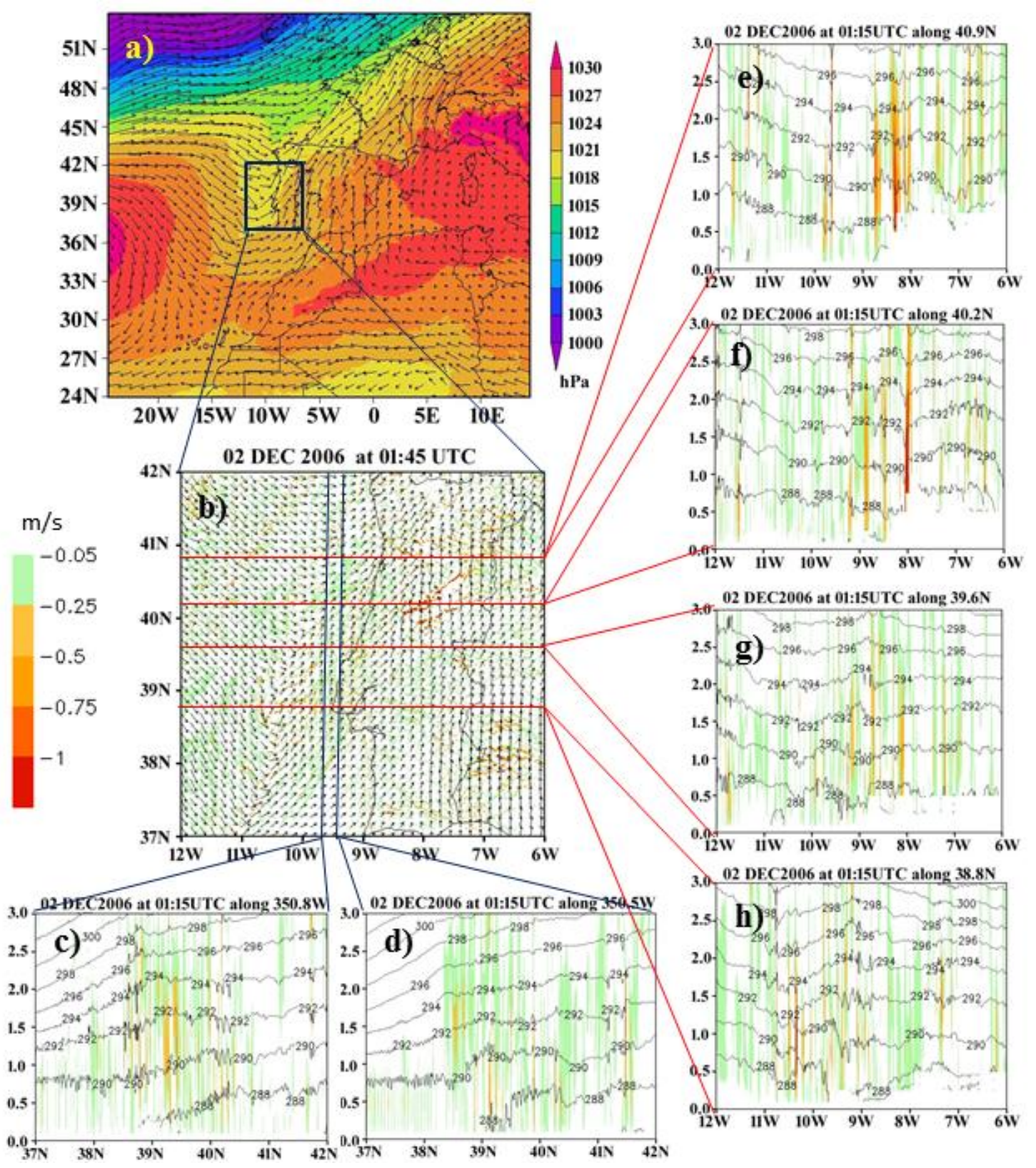




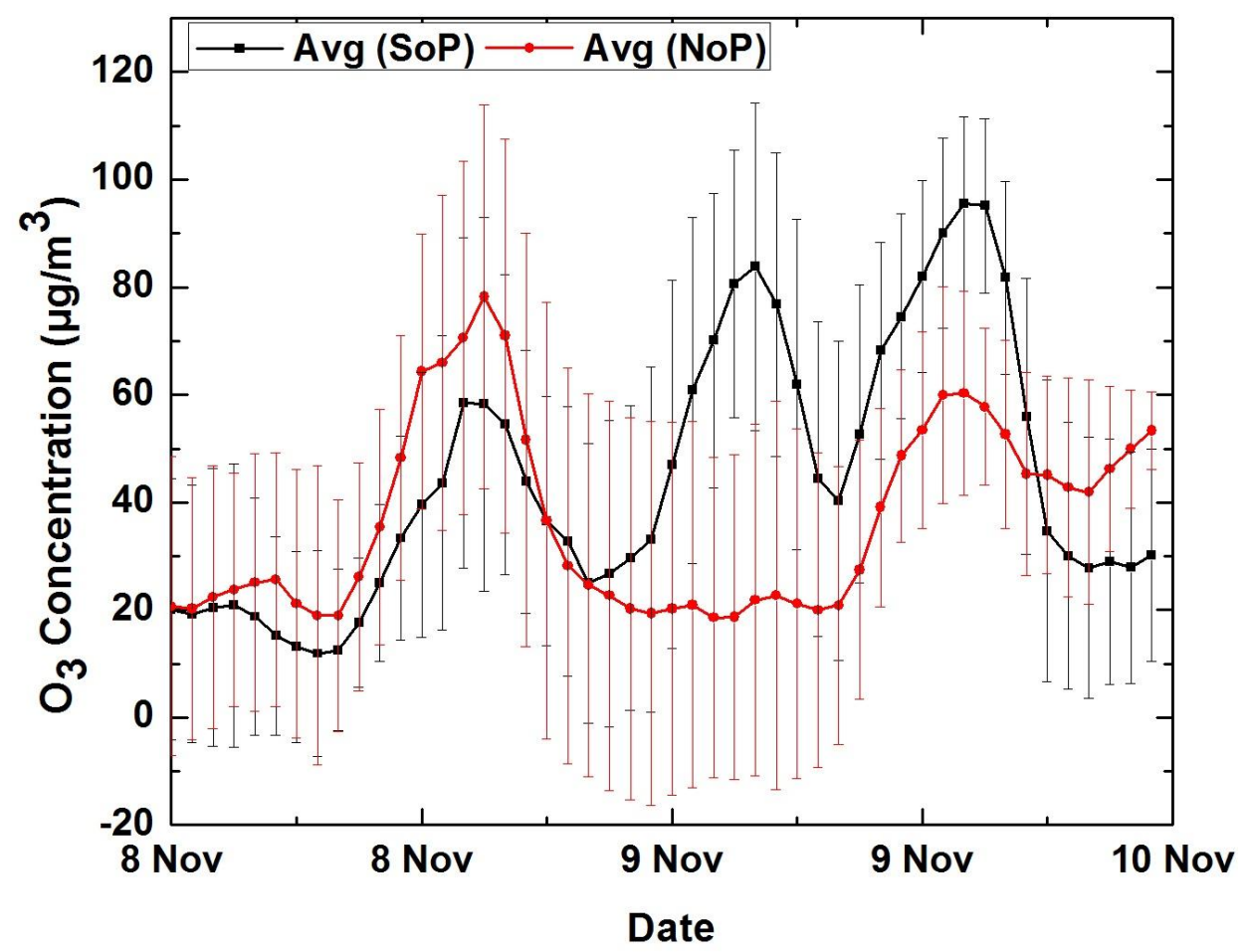




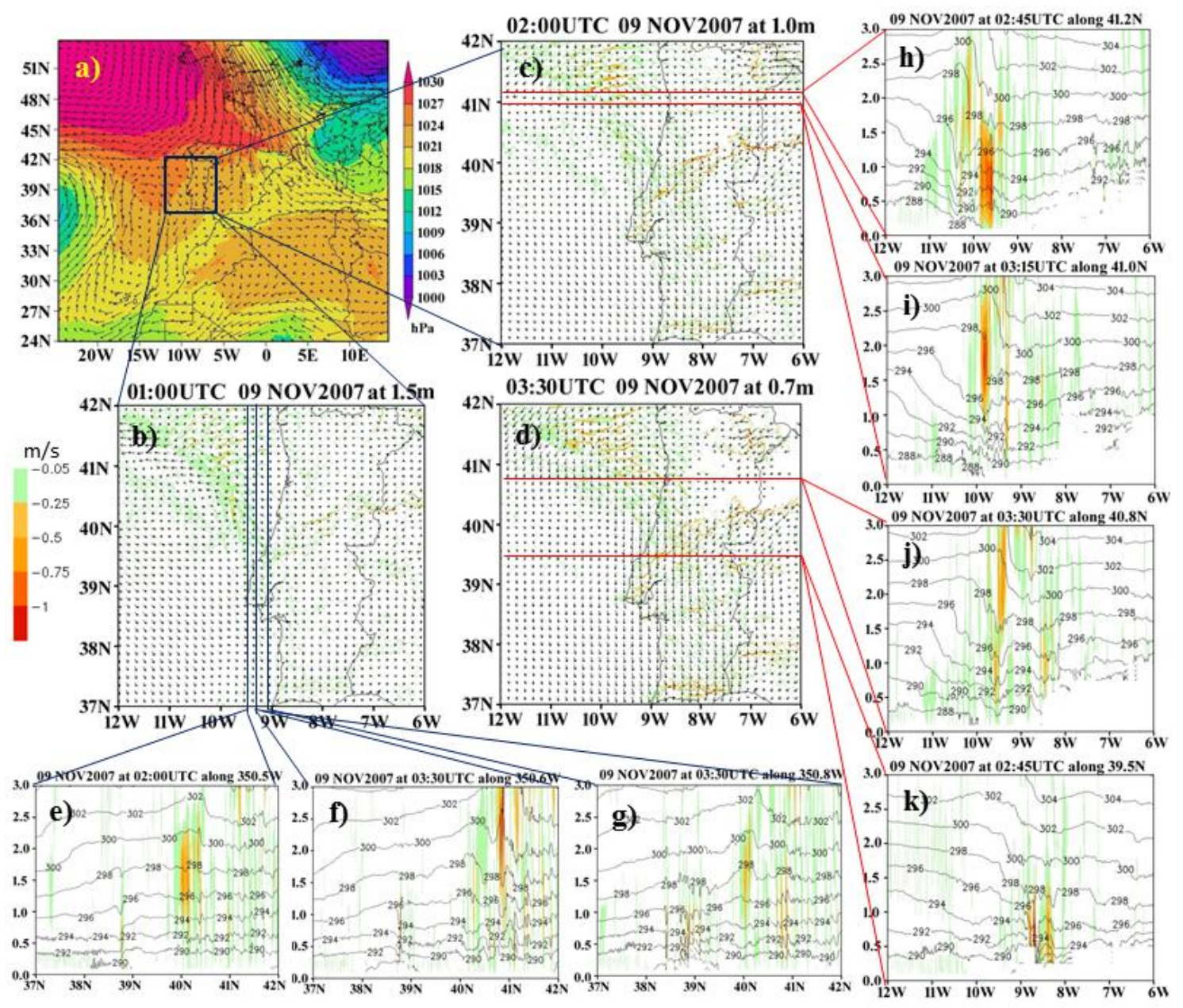




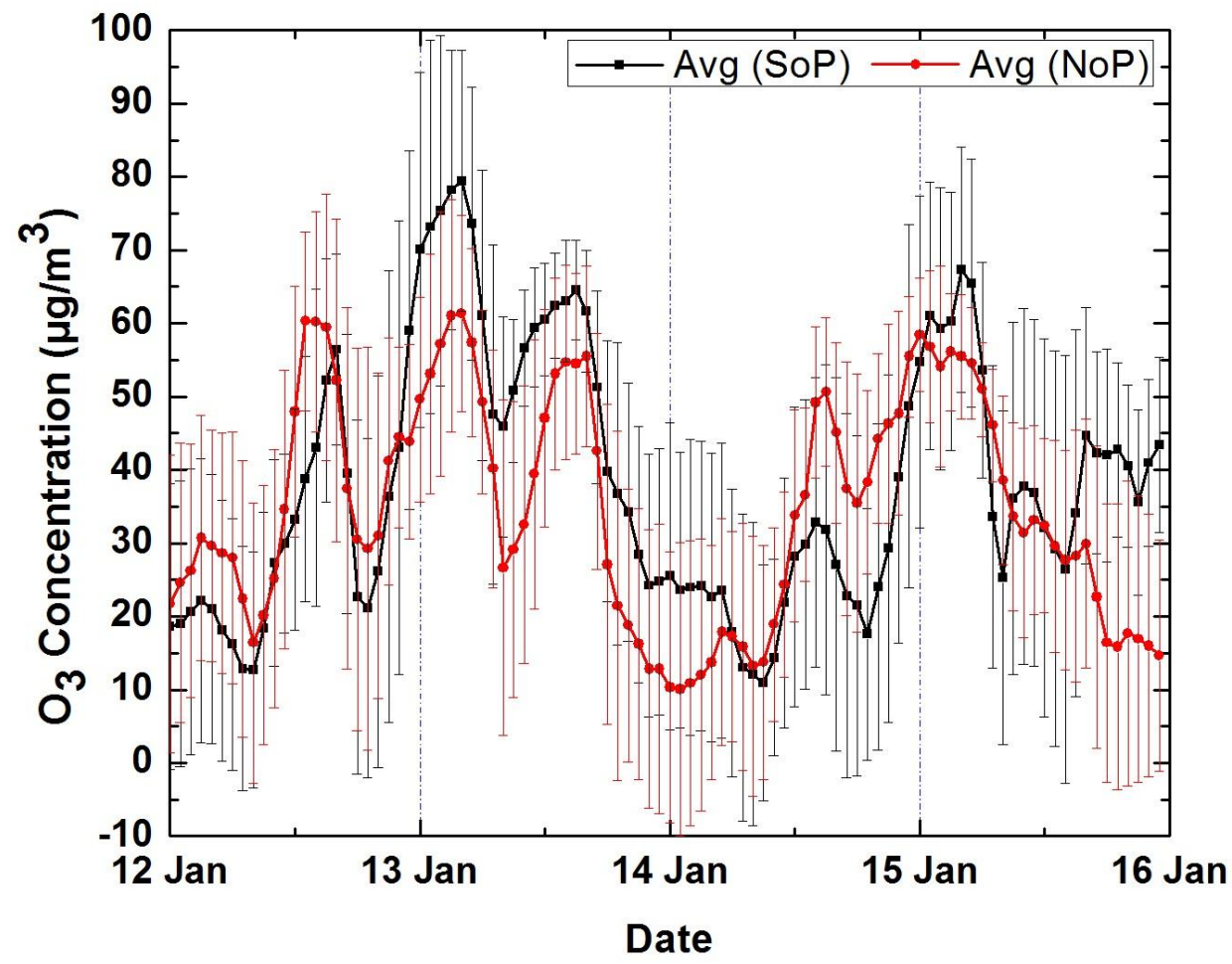



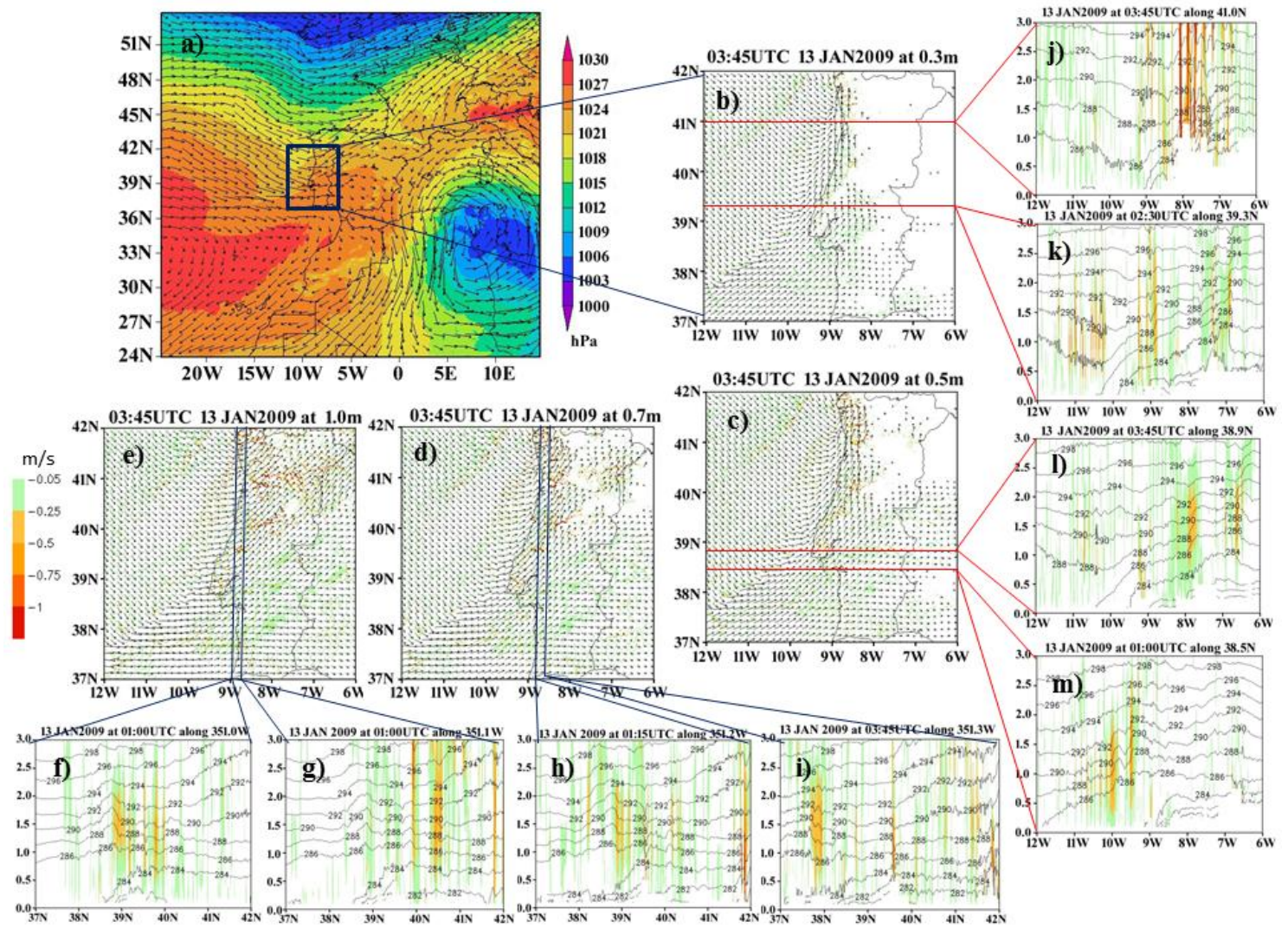
13.JAN2009 at 03:45UTC along 38.9

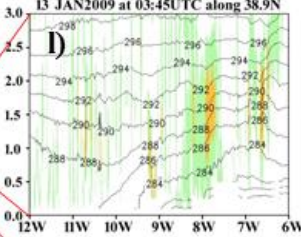
13. 3 N 2009 at 0:000UTC along 38.5N 2.5. m)

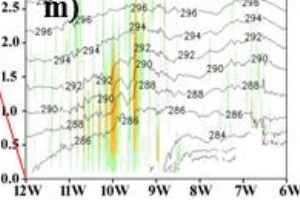


Tables:

Table 1: Details of Monitoring stations: name of the station, latitude-longitude-altitude co-ordinates, type of environment (ToE [Urban - U; Suburban - S; Rural - R]), type of influence (ToI [Background - B; Industrial - I; Trafic - T]), operational status and data availability $(\%)$.

\begin{tabular}{|c|c|c|c|c|c|c|c|c|c|}
\hline \multirow{2}{*}{ Station } & \multirow{2}{*}{ Lat } & \multirow{2}{*}{ Long } & \multirow{2}{*}{$\begin{array}{l}\text { Altitude } \\
\text { (masl) }\end{array}$} & \multirow{2}{*}{ ToE } & \multirow{2}{*}{ ToI } & \multicolumn{4}{|c|}{$\begin{array}{l}\% \text { of data available for each Event } \\
(\mathrm{N} \text { - station not operational) }\end{array}$} \\
\hline & & & & & & $\begin{array}{c}\text { Event } \\
1\end{array}$ & $\begin{array}{c}\text { Event } \\
2\end{array}$ & $\begin{array}{c}\text { Event } \\
3\end{array}$ & Event 4 \\
\hline Sonega & $37^{\circ} 52^{\prime} 16^{\prime \prime}$ & $-8^{\circ} 43^{\prime} 26^{\prime \prime}$ & 235 & $\mathrm{R}$ & I & 100.00 & 98.96 & 100.00 & 100.00 \\
\hline Monte Chãos & $37^{\circ} 57^{\prime} 15^{\prime \prime}$ & $-8^{\circ} 50^{\prime} 17^{\prime \prime}$ & 129 & $S$ & I & 100.00 & 100.00 & 100.00 & 100.00 \\
\hline Monte Velho & $38^{\circ} 04^{\prime} 37^{\prime \prime}$ & $-8^{\circ} 47^{\prime} 55^{\prime \prime}$ & 53 & $\mathrm{R}$ & B & 100.00 & 92.19 & 0.00 & 100.00 \\
\hline Arcos & $38^{\circ} 31^{\prime} 45^{\prime \prime}$ & $-8^{\circ} 53^{\prime} 39^{\prime \prime}$ & 2 & U & B & 100.00 & 99.48 & 100.00 & 99.31 \\
\hline Terena & $38^{\circ} 36^{\prime} 54^{\prime \prime}$ & $-7^{\circ} 23^{\prime} 51^{\prime \prime}$ & 187 & $\mathrm{R}$ & B & 100.00 & 100.00 & 100.00 & 100.00 \\
\hline Paio Pires & $38^{\circ} 37^{\prime} 10^{\prime \prime}$ & $-9^{\circ} 04^{\prime} 52^{\prime \prime}$ & 47 & $S$ & B & 100.00 & 99.48 & 100.00 & 100.00 \\
\hline Escavadeira & $38^{\circ} 39^{\prime} 31^{\prime \prime}$ & $-9^{\circ} 04^{\prime} 01^{\prime \prime}$ & 30 & $\mathrm{U}$ & I & 35.71 & 88.54 & 100.00 & 100.00 \\
\hline Laranjeiro & $38^{\circ} 39^{\prime} 49^{\prime \prime}$ & $-9^{\circ} 09^{\prime} 28^{\prime \prime}$ & 63 & $\mathrm{U}$ & B & 94.05 & 100.00 & 0.00 & 100.00 \\
\hline Quinta do Marquês & $38^{\circ} 41^{\prime} 51^{\prime \prime}$ & $-9^{\circ} 19^{\prime} 24^{\prime \prime}$ & 48 & $\mathrm{U}$ & B & 100.00 & 100.00 & 100.00 & 100.00 \\
\hline Restelo & $38^{\circ} 42^{\prime} 18^{\prime \prime}$ & $-9^{\circ} 12^{\prime} 37^{\prime \prime}$ & 143 & $\mathrm{U}$ & B & 100.00 & 100.00 & 100.00 & 99.31 \\
\hline Alfragide/Amadora & $38^{\circ} 44^{\prime} 20^{\prime \prime}$ & $-9^{\circ} 12^{\prime} 27^{\prime \prime}$ & 109 & $\mathrm{U}$ & B & 99.40 & 99.48 & 100.00 & 99.31 \\
\hline Entrecampos & $38^{\circ} 44^{\prime} 55^{\prime \prime}$ & $-9^{\circ} 08^{\prime} 56^{\prime \prime}$ & 86 & $\mathrm{U}$ & $\mathrm{T}$ & 100.00 & 100.00 & 100.00 & 94.44 \\
\hline Reboleira & $38^{\circ} 45^{\prime} 15^{\prime \prime}$ & $-9^{\circ} 13^{\prime} 51^{\prime \prime}$ & 132 & $\mathrm{U}$ & B & 100.00 & 100.00 & 98.96 & 98.61 \\
\hline Olivais & $38^{\circ} 46^{\prime} 08^{\prime \prime}$ & $-9^{\circ} 06^{\prime} 29^{\prime \prime}$ & 32 & $\mathrm{U}$ & B & 0.00 & 100.00 & 100.00 & 100.00 \\
\hline Mem Martins & $38^{\circ} 47^{\prime} 06^{\prime \prime}$ & $-9^{\circ} 20^{\prime} 50^{\prime \prime}$ & 173 & $\mathrm{U}$ & B & 100.00 & 100.00 & 100.00 & 99.31 \\
\hline Odivelas-Ramada & $38^{\circ} 48^{\prime} 08^{\prime \prime}$ & $-9^{\circ} 10^{\prime} 56^{\prime \prime}$ & 124 & $\mathrm{U}$ & I & 100.00 & 100.00 & 100.00 & 100.00 \\
\hline Loures-Centro & $38^{\circ} 49^{\prime} 47^{\prime \prime}$ & $-9^{\circ} 09^{\prime} 52^{\prime \prime}$ & 10 & $\mathrm{U}$ & B & 100.00 & 100.00 & 100.00 & 99.31 \\
\hline Beato & $38^{\circ} 53^{\prime} 41^{\prime \prime}$ & $-9^{\circ} 07^{\prime} 03^{\prime \prime}$ & 56 & $\mathrm{U}$ & B & 100.00 & 100.00 & 100.00 & 100.00 \\
\hline
\end{tabular}




\begin{tabular}{|c|c|c|c|c|c|c|c|c|c|}
\hline Chamusca & $39^{\circ} 21^{\prime} 09^{\prime \prime}$ & $-8^{\circ} 27^{\prime} 58^{\prime \prime}$ & 143 & $\mathrm{R}$ & B & 100.00 & 100.00 & 100.00 & 0.00 \\
\hline Ervedeira & $39^{\circ} 55^{\prime} 26^{\prime \prime}$ & $-8^{\circ} 53^{\prime} 30^{\prime \prime}$ & 60 & $\mathrm{R}$ & B & 99.40 & 100.00 & 100.00 & 100.00 \\
\hline $\begin{array}{l}\text { Instituto Geofísico de } \\
\text { Coimbra }\end{array}$ & $40^{\circ} 12^{\prime} 25^{\prime \prime}$ & $-8^{\circ} 24^{\prime} 39^{\prime \prime}$ & 145 & $\mathrm{U}$ & B & 100.00 & 100.00 & 98.96 & 100.00 \\
\hline Fundão & $40^{\circ} 13^{\prime} 59^{\prime \prime}$ & $-7^{\circ} 18^{\prime} 07^{\prime \prime}$ & 473 & $\mathrm{R}$ & B & 100.00 & 100.00 & 100.00 & 100.00 \\
\hline Ílhavo & $40^{\circ} 35^{\prime} 23^{\prime \prime}$ & $-8^{\circ} 40^{\prime} 14^{\prime \prime}$ & 32 & S & B & 100.00 & 100.00 & 100.00 & 99.31 \\
\hline Fornelo do Monte & $40^{\circ} 38^{\prime} 28^{\prime \prime}$ & $-8^{\circ} 06^{\prime} 02^{\prime \prime}$ & 741 & $\mathrm{R}$ & B & 98.81 & 91.15 & 100.00 & 99.31 \\
\hline Estarreja/Teixugueira & $40^{\circ} 45^{\prime} 24^{\prime \prime}$ & $-8^{\circ} 34^{\prime} 22^{\prime \prime}$ & 20 & $S$ & I & 100.00 & 100.00 & 100.00 & 99.31 \\
\hline Antas & $40^{\circ} 59^{\prime} 58^{\prime \prime}$ & $-8^{\circ} 37^{\prime} 24^{\prime \prime}$ & NA & $S$ & B & 100.00 & 100.00 & 98.96 & 100.00 \\
\hline Custóias & $41^{\circ} 11^{\prime} 59^{\prime \prime}$ & $-8^{\circ} 38^{\prime} 41^{\prime \prime}$ & 100 & S & B & 99.40 & 100.00 & 100.00 & 99.31 \\
\hline Ermesinde & $41^{\circ} 12^{\prime} 24^{\prime \prime}$ & $-8^{\circ} 33^{\prime} 10^{\prime \prime}$ & 140 & $\mathrm{U}$ & B & 99.40 & 100.00 & 100.00 & 100.00 \\
\hline Leça do Balio & $41^{\circ} 13^{\prime} 05^{\prime \prime}$ & $-8^{\circ} 37^{\prime} 56^{\prime \prime}$ & 40 & $S$ & B & 100.00 & 99.48 & 100.00 & 100.00 \\
\hline Perafita & $41^{\circ} 13^{\prime} 56^{\prime \prime}$ & $-8^{\circ} 42^{\prime} 47^{\prime \prime}$ & 25 & S & I & 100.00 & 100.00 & 98.96 & 94.44 \\
\hline Vermoim & $41^{\circ} 14^{\prime} 08^{\prime \prime}$ & $-8^{\circ} 37^{\prime} 07^{\prime \prime}$ & 90 & $\mathrm{U}$ & $\mathrm{T}$ & 100.00 & 99.48 & 100.00 & 100.00 \\
\hline Vila Nova da Telha & $41^{\circ} 15^{\prime} 08^{\prime \prime}$ & $-8^{\circ} 39^{\prime} 38^{\prime \prime}$ & 88 & S & B & 100.00 & 100.00 & 100.00 & 100.00 \\
\hline
\end{tabular}


Table 2: Details of four NSO enhancement events.

\begin{tabular}{llrcrr}
\hline $\begin{array}{l}\text { Event } \\
\text { No. }\end{array}$ & $\begin{array}{l}\text { Start } \\
\text { date }\end{array}$ & End date & $\begin{array}{l}\text { Duration } \\
(\text { nights })\end{array}$ & $\begin{array}{l}\text { Maximum } \\
\text { intensity }\left(\boldsymbol{\mu g} / \mathbf{m}^{3}\right)\end{array}$ & $\begin{array}{l}\text { No. of stations with } \\
\mathbf{N S O ~ c o n c} \mathbf{n}^{\mathbf{n}} \geq \mathbf{8 0} \boldsymbol{\mu g} / \mathbf{m}^{3}\end{array}$ \\
\hline Event 1 & 5 Jan 06 & 7 Jan 06 & 2 & 88 & 5 \\
Event 2 & 1 Dec 06 & 7 Dec 06 & 6 & 93 & 6 \\
Event 3 & 8 Nov 07 & 9 Nov 07 & 1 & 124 & 13 \\
Event 4 & 12 Jan 09 & 15 Jan 09 & 3 & 97 & 15 \\
\hline
\end{tabular}

